\title{
Drie meditasies oor Istanbul
}

\section{Istanbul, 'n meditasie}

In 'n droom tussen wakker en slaap, 'n tydverskil tussen kontinent en on-vasteland hoor ek hierdie woorde aan my gefluister op laataand televisie:

"'n Klein pistachio-neut oopgebreek openbaar sy ware aard: harde dop met murgsagte binnegoed." Ek vaar oor die Bosphorus, trek my skoene uit in die Blou Moskee, staan in die Hagia Sofia, onverwoesbaar deur soveel brande, aardbewings, teenstand.

Stad van die Chora,

kerk, tempel of moskee:

Sy gesig orals gemosaïek, 'n Geel Lig van Wysheid omvou dié stad van die Vader, Seun en Heilige Gees, teen soveel aanslae bestand.

\section{Istanbul, 'n meditasie}

In 'n troebel droom

skeur ek die binneblad van 'n boek uit, daar waar die biblioteekdatumstempel staan. Die boek handel oor hulle, die dooies, die vertrekkendes, wat soms in drome hul opwagting maak of in vreemde stede op 'n haar na lyk soos 'n inwoner van 'n stad, maar praat met ' $n$ vreemde tongval, verbaas opkyk en nooit teruggroet nie of in 'n glaskas van 'n museum uitgestrek lê en onsiende staar. Hulle lewens was op bruikleen. Dit het nooit aan hul behoort nie. Hulle lewens was ' $n$ blote storie en die Outeur se naam in die kolofon blyk te wees 'n skuilnaam. Daardie Naam is die een waarna ek bly soek. Vannag lees ek daardie geleende boek oor die lewens van my vriende, my vader en almal wat my pad gekruis het. Oor 'n lewe uitgeneem in die biblioteek van die Dood.

\author{
Istanbul, 'n meditasie \\ Slotte is ook sleutels (soekend) sleutels ook slotte, \\ na "closure", na Saul Bellow se "quiet space". \\ Helaas geluk dit my nie; die sleutel toegesluit \\ in die Royal Hotel op die vierde verdieping. \\ Jy sal waarskynlik opmerk:"unresolvable plot", \\ my attent maak dat die Bosphorus dit reeds uitwys: \\ dat sluiting of eindes in 'n postmodernistiese tyd nie deug. \\ Hierom dan 'n gedig, gedagtig aan VWL se slotte, \\ wéér 'n vaart oor die rivier en nadink oor DJO: \\ "alles stroom deur grens en eeu aaneen." \\ Allersieledag vir my in 'n stad vol tekens, intertekste \\ en veral, museums gevul met verlore slotte. \\ En alles bly helaas hier tussen aanhalingstekens.
}

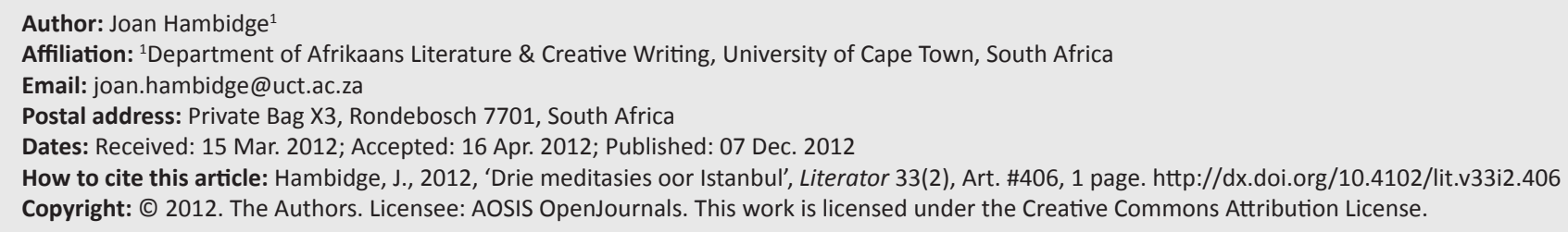

